\title{
PURA MEKAH DI BANJAR ANYAR DESA POH GADING, UBUNG KAJA, KOTA DENPASAR (Analisis Struktur, Historis dan Fungsi)
}

\author{
I Nyoman Djuana \\ Universitas Warmadewa \\ Denpasar \\ e-mail: nyomannuratni@gmail.com \\ Ni Made Surawati \\ Universitas Hindu Indonesia \\ Denpasar \\ e-mail: madesurawati@yahoo.co.id
}

\begin{abstract}
This article discusses the existence of Pura Mekah in Banjar Binoh Ubung Kaje by using structural analysis, history and function. The existence of Pura Mekah in Banjar Binoh is interesting to be studied because if seen from its name as related to holy place of Moslem. Historically this temple is associated with the coming of Majapahit to Bali. Based on oral discourse it is stated that in Ubung (formerly a village with Peguyangan) ever came two messengers of Majapahit which touted as Dalem Mekah. These two messengers lived with a restricted setra Dalem Poh Gading, one living in the north of Setra (Pura Mecca Banjar Anyar) and the other living in the south. The structure of Pura Mekah is different from the general structure of the temple in Bali that is using the concept of Tri Mandala, while in Pura Mekah only Dwi Mandala. Functionally, the temple is functioning religiously and socially.
\end{abstract}

Keywords: Pura Mekah, History, Structure and Function

\begin{abstract}
Abstrak
Artikel ini membahas tentang keberadaan Pura Mekah di Banjar Binoh Ubung Kaje dengan menggunakan analisis struktur, sejarah dan fungsi. Keberadaan Pura Mekah di Banjar Binoh memang menarik dikaji karena jika dilihat dari namanya seperti berhubungan dengan tempat suci umat Islam. Secara historis Pura ini berhubungan dengan datangnya Majapahit ke Bali. Berdasarkan wacana lisan dinyatakan bahwa di Ubung (yang dulunya satu desa dengan Peguyangan) pernah datang dua utusan Majapahit yang disebut-sebut sebagai Dalem Mekah. Dua utusan ini tinggal dengan dibatasi setra Dalem Poh Gading, yang satu tinggal di sebalah utara setra (Pura Mekah Banjar Anyar) dan satunya lagi tinggal


di sebelah selatan. Struktur Pura Mekah berbeda dengan struktur umum pura di Bali yakni menggunakan konsep Tri Mandala, sementara di Pura Mekah hanya Dwi Mandala. Secara fungsional, pura ini berfungsi secara religius dan sosial.

Kata Kunci: Pura Mekah, Sejarah, Struktur dan Fungsi

\subsection{Pendahuluan}

Pura adalah wilayah yang diyakini sebagai tempat sakral yaitu Hyang Widhi dengan segala manifestasi-Nya menganugrahkan kebahagiaan. Pura yang merupakan bangunan suci Hindu tersebar sampai ke pelosok-pelosok dan hampir di setiap tempat yang menjadi hunian masyarakat Hindu. Pada umumnya struktur wilayah pura dibagi menjadi tiga bagian yang disebut Tri Mandala yaitu: utama mandala, madya mandala, nista mandala, dan pura/palinggih tempat berstananya Hyang Widhi dengan segala manifestasiNya adanya pada utama mandala.

Dari wilayah suci inilah tatanan sosial Hindu di Bali dimulai. Jadi tatanan sosial yang muncul dari wilayah sakral ini menjadi fakta sosial yang mengatur prilaku umat Hindu di Bali. Sampai saat ini pura masih tetap menjadi pusat orientasi dan tetap lestari. Karena itu para wisatawan sering menyebut Bali dengan nama The Island of thousand Tampels atau The Island of Gods (Ardana, 1994:1).

Berkembangnya Agama Hindu di Bali tidak lepas dari datangnya Mpu Kuturan yang membawa konsep Tri Murti yang digunakan sebagai pegangan hidup masyarakat Bali. Konsep ini lahir lewat diadakannya Pesamuan Agung Tiga (pertemuan) I dan II antara Mpu Kuturan dengan tokoh masyarakat Bali. Keputusan yang dihasilkan dalam pertemuan ini antara lain: (1) Pada setiap desa adat atau desa pakraman harus ada Kahyangan Tiga, mencakup Pura Desa atau Bale Agung, Pura Puseh atau Pura Segara dan Pura
Dalem, (2) Pada setiap rumah pekarangan harus didirikan bangunan suci yang disebut Sanggahatau Merajan"(Soebandi,1981:47).

Berawal dari pesamuan itulah istilah Kahyangan Tiga dilaksanakan sepenuhya di Bali yang meliputi Pura Desa, Pura Puseh dan Pura Dalem. Ini sebagai simbol dari tiga lingkaran hidup manusia yaitu lahir, hidup dan mati. Pura Desa simbol dari penciptaan hidup, Pura Puseh simbol dari pemeliharaan hidup, dan Pura Dalem sebagai simbol dari penguasaan maut. Semenjak itu seluruh desa adat di Bali memiliki Pura Kahyangan Tiga (Putra,1999: 103).

Berdasarkan karakteristiknya ribuan Pura yang terdapat di Pulau Bali diklasifikasikan menjadi empat kelompok: (1) Pura Kahyangan Jagat, yaitu pura umum tempat pemujaan Sang Hyang Widhi Wasa, Tuhan Yang Maha Esa dalam segala manifestasi-Nya, roh suci para tokoh masyarakat seperti pendeta dan penguasa. Yang termasuk di dalamnya adalah Pura Sad Kahyangan, yaitu enam pura terbesar di Pulau Bali dan Pura Dang Kahyangan, (2) Pura Kahyangan Desa, yaitu pura tertorial tempat pemujaan warga desa adat, (3) Pura Swagina (Pura fungsional) yaitu pura yang penyiwinya terikat pada pencaharian seperti Pura Subak, Pura Melanting dan yang sejenisnya. (4) Pura Kawitan, yaitu pura yang penyiwinya seperti Sanggah/Merajan, Pertiwi, Ibu, Panti, Dadia, Batur, Penataran Dadia, Dalem Dadia, Pedharman dan yang sejenisnya.

Ditegaskan pula bahwa selain kelompok pura yang mempunyai fungsi dan 
karakterisasi seperti tersebut di atas, terdapat pula pura yang berfungsi di samping untuk memuja Hyang Widhi Wasa atau PrabawaNya, juga berfungsi untuk memuja Atma Sidha Dewata (Rokh Suci Leluhur).

Palinggih Penyawangan yang terdapat di kantor-kantor, sekolah-sekolah dan sejenis dengan itu dapat dikelompokkan ke dalam kelompok Pura Jagat/ Umum karena sebagai tempat pemujaan Prabawa tertentu dari Hyang Widhi Wasa. Selanjutnya juga dikatakan Landasan Dasar Pura Sad Kahyangan Jagat di Bali berlandaskan pada: (1) Landasan Filosofis yaitu konsepsi Sad Winayaka (menurut lontar Dewa Purana Bangsul), (2) Landasan Historis yaitu Pura Sad Kahyangan itu sudah ada sebelum kedatangan Gajah Mada di Bali tahun 1343 M, (3) Landasan Tradisi yaitu masyarakat di Bali pada umumnya telah memandang bahwa pura-pura itu adalah Sad Kahyangan Jagat di Bali.

Ditinjau dari segi rumusannya Pura Kahyangan Jagat di Bali yaitu: a) Yang berlandaskan konsepsi Rwabhineda ialah: (1) Pura Besakih sebagai Purusha di Kabupaten Karangasem, (2) Pura Batur Sebagai Pradhana di Kabupaten Bangli. b) Yang berlandaskan konsepsi Catur Lokapala ialah : (1) Pura Lempuyang Luhur di Kabupaten Karangasem, (2) Pura Andakasa di Kabupaten Karangasem, (3) Pura Batukaru di Kabupaten Tabanan, (4) Pura Pucak Mangu di Kabupaten Badung. c) Yang berlandaskan konsepsi Sad Winayaka ialah: (1) Pura Besakih di Kabupaten Karangasem, (2) Pura Lempuyang di Kabupaten Karangasem, (3) Pura Goa Lawah di Kabupaten Klungkung, (4) Pura Uluwatu di Kabupaten Badung, (5) Pura Batukaru di Kabupaten Tabanan, dan (6) Pura Puser Tasik di Kabupaten Gianyar. Kahyangan Jagat yang berlandaskan Konsepsi Sad Winayaka inilah yang dimaksud Pura Sad Kahyangan Jagat di
Bali (Suhardana,2006:18).

Secara historis, Pura adalah warisan yang akarnya bermula dari jaman prasejarah Bali. Sebagaimana halnya keberadaan candi di Jawa. Pura berwujud punden berundak yaitu reflika gunung yang difungsikan untuk memuja roh para leluhur (Ardana dalam Kartika, 2008: 2). Setelah Bali memasuki jaman sejarah, yaitu ketika raja-raja Bali mulai menjalin hubungan dengan raja-raja yang menganut agama Hindu di Pulau Jawa (dari abad ke - 8 sampai abad ke-15) keberadaan punden berundak tersebut lambat laun berkembang menjadi pura dan lestari sebagaimana diwarisi di Bali dewasa ini.

Artinya dari kacamata budaya wujud pura sebagaimana diwarisi dewasa ini adalah salah satu hasil akulturasi antara tradisi kecil Bali dengan tradisi besar yang berasal dari India (Geriya, 2000:2). Orang India datang ke daerah kebudayaan Nusantara dalam 3 gelombang, yakni awal abad ke-4, abad ke-8 sampai ke-9, dn abad ke-11. Orang-orang India itu membawa Agama Hindu dan Budha serta kebudayaan dari tanah asalnya. Selama bertahun-tahun kebudayaan Nusantara berada di bawah kekuasaan kebudayaan Hindu (Winstedt dalam Suastika, 1996:140).

Akan tetapi beberapa bukti faktual misalnya bentuk bangunan suci di Jawa (Candi) menunjukkan bahwa kebudayaan India tidak mendominasi kebudayaan asli Jawa melainkan terjadi asimilasi yang indah antara keduanya. Lokal genius Jawa menjadi penyaring masuknya budaya Hindu India sehingga Hindu di Jawa hidup dengan kebudayaan asli orang Jawa dan menjadikannya sebagai agama Hindu yang khas dan berpenampilan berbeda dari tanah kelahirannya, India.

\begin{tabular}{lllr}
\multicolumn{1}{c}{ Proses } & dialektis ini & rupanya \\
berlangsung & terus menerus & dalam \\
perkembangan & agama & Hindu di & seluruh
\end{tabular}


nusantara sehingga Hindu nusantara menampakkan diri sesuai dengan karakter lokal. Hindu Jawa, Hindu Bali, Hindu Kaharingan, Hindu Dayak, dan lainnya menjadi karakter-karakter khas Hindu nusantara yang jauh dari kesan uniformalitas.

Di Bali Pura juga merupakan bukti sejarah yang masih dilestarikan dan dijaga keberadaannya. Pura-pura di Bali kebanyakan menyimpan keunikan sendiri yang bisa dilihat daritinggalan-tinggalannya. Seperti pura Kebo Edan di Pejeng, Pura Pengukur-ukuran, Pura Goa Gajah, Pura Gunung Kawi, Pura Mangening, Pura Batur dan banyak lagi.

Ada pula Pura yang menunjukkan Bali sebagai sebuah nusantara kecil tidak disekatsekat oleh agama. Itu dibuktikan dengan ada Pura yang bernama Pura Mekah yang menunjukkan pengakuan terhadap agama Muslim di daerah Denpasar Utara. Keberadaan Pura Mekah ini sangat menarik karena beberapa alasan, pertama nama pura yang diidentikkan dengan sebuah tempat suci sentrum orientasi Umat Muslim di Timur tengah, kedua pura ini ada di wilayah pemukiman kelas menengah urban kota, tepatnya di Banjar Anyar, Ubung Kaja Denpasar, dan ketiga dalam pelaksanaan upacara ritual tidak menggunakan daging babi, dan keempat terdapat keunikan yang bisa ditelusuri secara historis yakni keberadaan Pura Mekah yang lebih dari satu di kisaran Ubung Kaja, dan kelima sistem pemujaan juga sedikit berbeda yakni menggunakan arah barat sebagai arah kiblat.

Keberadaan Pura Mekah di Banjar Anyar Desa Poh Gading, Ubung Denpasar ini menandakan telah terjadi asimilasi atau 'koalisi' kultural antara kebudayaan Hindu dan Muslim di tengah kian gencarnya kasuskasus kekerasan mengatasnamakan agama dan krisis multidimensi.

\subsection{Pembahasan}

\subsubsection{Sejarah Keberadaan Pura Mekah di Banjar Anyar}

Melacak sejarah keberadaan Pura Mekah di Banjar Anyar, Desa Poh Gading Ubung Kaja memang bukanlah pekerjaan mudah. Minimnya data-data tertulis baik berupa lontar babad, prasasti, begitu juga sumber lisan dari para penglingsir mempersulit melakukan penelusuran sejarah keberadaan pura ini. Namun demikian, peneliti melakukan penelusuran dengan menggunakan pola interteks dan mengakomodir mitos-mitos yang memiliki relevansi dengan keberadaan Pura Mekah ini. Sebagai disampaikan Berg (1985:3) penelusuran masa lalu menggunakan cerita atau mitos kiranya masih dimungkinkan (Berg, 1985: 3).

Sementara menurut Sartono Kartodirdjo salah seorang sejarawan Indonesia (dalam Susanto dkk (eds), 2003:148-149) bahwa kelemahan penulisan sejarah selama ini karena selalu saja hanya menghandalkan sumber-sumber dokumen atau arsip (artefact), belum banyak menggunakan sumber mentifact (fakta mental) maupun sumber socifact (fakta sosial). Fakta mental yang dimaksud dalam hal ini dianggap dekat dengan ingatan (memory) sosial kemasyarakatan yang diteliti. Generalisasi fakta mental masyarakat biasanya terdiri atas ide, gagasan, pandangan, orientasi nilai, mitos dan segala macam struktur kesadaran dalam masyarakat.

Menurut seorang pemangku Pura Mekah bernama I Wayan Mertha (wawancara 5/4/2016), keberadaan Pura Mekah di Poh Gading Ubung Kaja memiliki kaitan dengan Pura Mekah yang berada di Desa Binoh. Hal ini diperkuat dengan adanya wacana lisan yang menyatakan jika di Ubung (yang dulunya satu desa dengan Peguyangan) pernah datang dua utusan Majapahit yang disebut-sebut sebagai Dalem Mekah. Dua 
utusan ini tinggal dengan dibatasi setra Dalem Poh Gading, yang satu tinggal di sebalah utara setra dan satunya lagi tinggal di sebalah selatan.

Dari informasi yang di dapat ini cukup masuk akal, karena berdasarkan penelusuran lapangan di Ubung memang terdapat dua Pura Mekah yang berada di Banjar Anyar yang menjadi obyek penelitian penulis dan satunya lagi terletak di Desa Binoh. Menurut Wayan Mertha keduanya ini diperkiran bersaudara kakak-beradik. Namun menurut Mertha terdapat perbedaan tradisi ritual di kedua pura ini, sehingga pihaknya pun dibuat bingung. Kendati demikian, Mertha juga meyakini jika kedua Pura Mekah ini memiliki hubungan sejarah. Berikut penuturannya kepada peneliti.

"Saya benar-benar tidak tahu pastinya. Tapi menurut penuturan katanya Pura Mekah ini memiliki kaitan dengan Pura Mekah di Binoh. Dua Pura Mekah ini hanya dibatasi setra dan berada di Desa Peguyangan. Dulu ini jadi satu dengan Desa Peguyangan sebelum berpisah. Tapi ada perbedaan dalam melakukan upacara ritual di kedua Pura Mekah ini. Itu saya kurang paham".

Penuturan Mertha ini memperjelas jika memang kedua pura ini memiliki hubungan sejarah dan hanya dipisahkan oleh setra Dalem. Tidak puas dengan penjelasan lisan yang singkat tersebut, peneliti juga menelusuri sejarah keberadaan Pura Mekah di Binoh untuk mencari benanh merah keberadaan Pura Mekah di Banjar Anyar. Tidak seperti Pura Mekah di Banjar Anyar, Mekah di Binoh ternyata memiliki peninggalan berupa lontar yang menunjukkan historis keberadaannya.

Di Pura Mekah Binoh terdapat lontar berukuran panjang $31,5 \mathrm{~cm}$, lebar 3,48 berjumlah 34 lembar. Isi lontar tersebut pernah diteliti oleh tim Arkeologi Departemen Kebudayaan dan Pariwisata Provinsi Bali di tahun 2007. Hasilnya adalah sebuah alih aksara lontar dan transliterasi dari bahwa Jawa Kuno ke bahasa Indonesia.

Menurut penyungsung pura Mekah di Binoh bernama Ketut Murnia (wawancara, 7/4/2016), isi dari lontar tersebut yakni silsilah seorang patih yang dikirim dari kediri ke Bali yakni Sri Kresna Kepakisan. Ia adalah keturuan Aryeng Kediri Putra dari Jayasabha. Tim ahli arkeologi yang terdiri dari I Gusti Made Suarbhawa, Nyoman Sunarya dan Made Geria juga mengkaji bahwa naskah itu berisi tentang persebaran keturunan Sri Kresna Kepakisan ke pelosok Bali. Namun demikian, dalam lontar tersebut justru tidak menyebutkan keberadaan Pura Mekah di Binoh begitu juga tahun pendiriannya. Berikut penuturan Murnia.

"Di pura ini memang terdapat peninggalan berupa lontar. Saya tidak tahu isi lontarnya, tapi menurut tim arkeologi tersebut isi lontar ini adalah silsilah seorang patih Raja bernama sri Kresna Kepakisan. Diperkirakan Dalem Mekah adalah pengiring beliau ketika datang ke Bali. Namun ini hanya penafsiran saya saja. Karena di dalam lontar itu memang tidak detil menyebutkan sejarah Pura Mekah".

Murnia pun mereka-reka jika merujuk pada nama Sri Kresna Kepakisan, maka besar kemungkinan catatan yang ditemukan di Pura Mekah Binoh merupakan catatan silsilah seorang keturunan Sri Kresna Kepakisan, atau juga pengikut beliau yang dibawa dari Jawa Timur. Sri Kresna Kepakisan merupakan seorang patih yang ditugaskan Gajah Mada ke Bali untuk menjadi raja di Bali setelah Sri Astasura Ratma Bumi Banten ditaklukkan Majapahit. 
Namun apabila dilihat dari arsitektur bangunan, candi gelung di Pura Mekah Binoh, pura ini dibangun dengan sentuhan kebudayaan Islam saat itu. Terbukti di atas candi gelung itu terdapat gempolan seperti kubah. Menurut Murnia para arkeolog yang pernah melakukan penelitian juga menyatakan hal yang demikian. Satu hal lagi, status Pura Mekah di Binoh ini hampir sama dengan Pura Mekah di Banjar Anyar.

Keduanya bukan merupakan pura umum, melainkan Pura Kawitan yang hanya diempon oleh beberapa keluarga besar saja. Seperti juga yang disampaikan pemangku Pura Mekah Banjar anyar bapak I Wayan Mertha, bahwa puranya hanya diempon oleh beberapa kepala keluarga saja, karena pura itu memang pura keluarga. Ketika ada piodalan, sekitar 60 kepala keluarga ikut terlibat di dalamnya.

Berdasarkan penelusuran lisan dan upaya mengkait-kaitkan antarsatu data dengan data yang lain, menurut peneliti sangat besar kemungkinan jika keberadaan dua pura ini memiliki hubungan historis tertentu. Apalagi keberadaan pura ini memang hanya dibatasi oleh setra Dalem Desa Pakraman Poh Gading saja sebagaimana disampaikan I Wayan Mertha.

Artinya bisa diprediksi jika keberadaan Pura Mekah di Banjar Anyar tidak bisa dilepaskan dari sejarah trah Majapahit di Bali khususnya patih beliau Sri Kresna Kepakisan. Bisa ditegaskan kembali, keberaan Pura Mekah di Banjar Anyar dan Binoh merupakan hubungan kakak-beradik. Hanya saja di kedua pura ini memiliki cara dan tradisi pemujaan yang berbeda.

\subsubsection{Struktur Pura Mekah di Banjar Anyar}

\subsubsection{Dwi Mandala}

Pada umumnya struktur atau denah pura di Bali dibagi atas 3 bagian yaitu: jaba sisi (halaman luar), jaba tengah (halaman tengah), dan jeroan (halaman dalam). Disamping itu ada juga pura terdiri dari 2 (dua) halaman yaitu : jaba pura (halaman luar) dan jeroan (halaman dalam) dan ada juga terdiri 7 (tujuh) halaman (tingkatan) seperti Pura Agung Besakih. Pembagian halaman pura ini didasarkan atas konsepsi makrokosmos (bhuwana agung), yakni pembagian pura atas 3 (tiga) bagian halaman adalah lambang Tri Loka yaitu bhur loka (bumi), bwah loka (langit) dan swah loka (sorga).

Pembagian pura atas 2 (dua) halaman melambangkan (urdhah) dan alam bawah (adhah) yaitu akasa dan pretiwi. Sedangkan pembagian pura atas 7 (tujuh) bagian (halaman) melambangkan sapta loka yaitu tujuh lapisan atau tingkatan alam atas terdiri dari bhur loka, bhwah loka, swah loka, maha loka, jana loka, tapala loka dan satya loka. Dan pura yang terdiri dari satu halaman adalah simbolis dan Eka Bhuwana yaitu penunggalan antara alam bawah dengan alam atas.

Hal ini diperkuat dengan gagasan yang berpatokan pada sistem perpadanan antara makrokosmos dengan mikrokosmos. Semakin tepat penerapan sistem perpadanan, maka semakin besar peluang bagi masyarakat untuk mewujudkan kerahayuan maupun kesejahteraan hidup mereka. Berkenaan dengan hal itu menurut kosmologi Hindu alam semesta atau makrokosmos dengan lingkungan harus berpadanan secara horisontal yang terbagi menjadi 3 (tiga) bagian yang disebut Tri Angga. Tri Bhuwana atau Tri Loka yakni (1) alam atas, kepala atau swah yaitu kawasan pegunungan; (2) alam tengah, badan atau bhuwah terletak antara gunung dan laut; dan (3) alam bawah, kaki, teben atau keluar kawasan pantai. Ketiga kawasan itu memiliki nilai utama suci atau sakral, madya suci profan dan nista profan.

Pembagian secara horisontal itu 


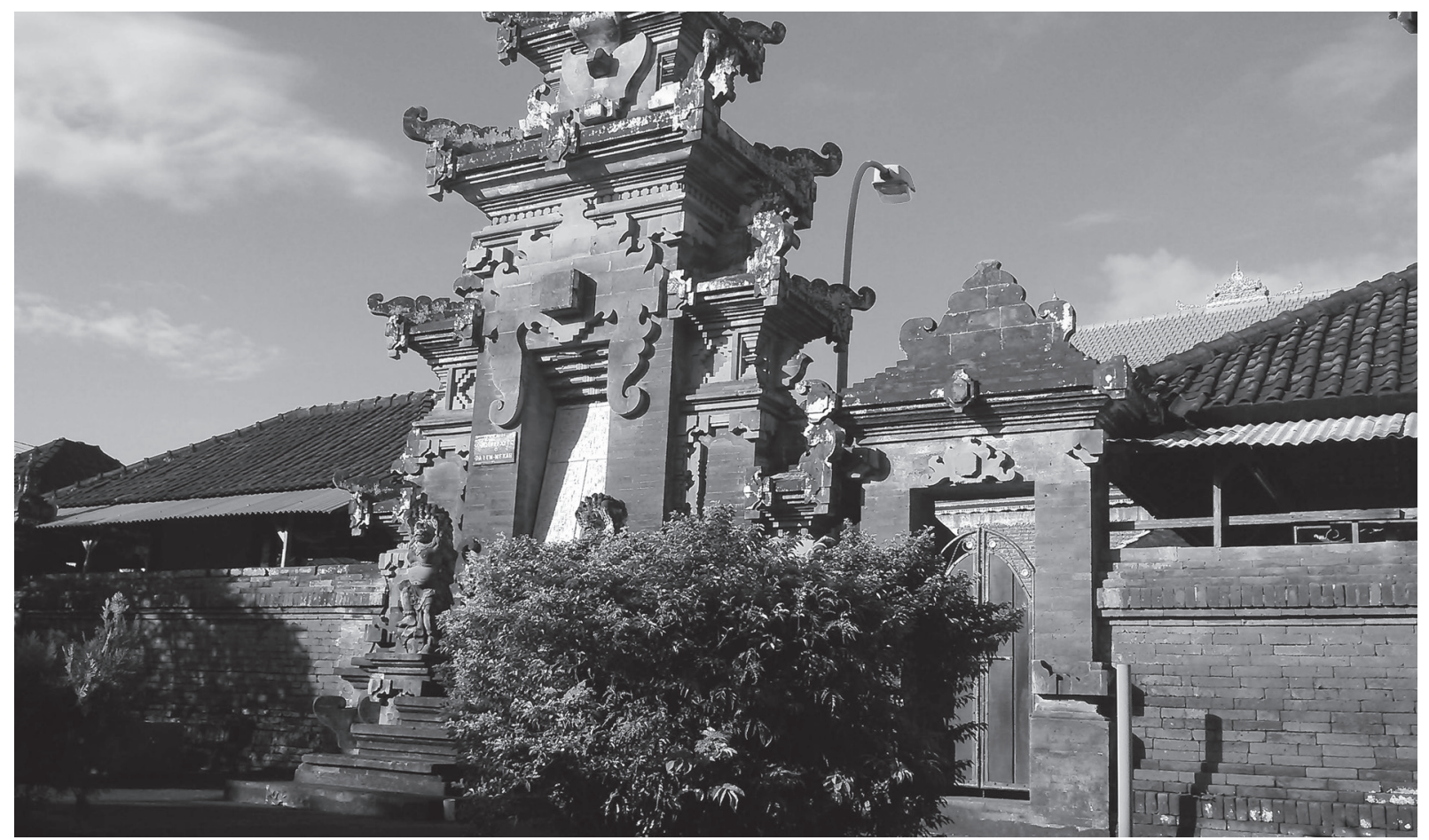

Gambar Gelung Kori Pura Mekah

Dokumentasi Pribadi

melambangkan prakerti (unsur materi alam semesta), sedangkan pembagian secara vertikal adalah simbolis purusa atau (unsur kejiwaan, spiritual alam) (Wiana 2001: 101). Peninggalan konsepsi prakerti dengan purusa dalam struktur pura merupakan simbolis dari super natural. Hal itulah yang menyebabkan orang-orang dapat merasakan adanya getaran spiritual atau super natural power (Tuhan Yang Maha Esa) dalam sebuah pura.

Sebuah pura dikelilingi dengan tembok (panyengker) sebagai batas pekarangan yang disakralkan. Pada sudutsudut pura dibuatlah paduraksa (penyangga sudut) yang berfungsi menyangga sudutsudut pekarangan tempat suci. Adapun ketiga halaman pura pada umumnya terdapat beberapa buah bangunan yang antara lain pada halaman depan atau luar terdapat bangunan berupa bale kulkul (balai tempat kentongan digantung), bale wantilan, bale pewargan atau dapur dan jineng (lumbung).
Halaman kedua disebut jabaan tengah terdapat bangunan bale agung (balai panjang) dan bale pagongan (balai tempat gambelan). Sedangkan halaman yang ketiga disebut jeroan (halaman dalam), halaman yang paling suci terdapat bangunanbangunan pelinggih sebagai stana Tuhan Yang Maha Esa dan para dewa dengan manifestasinya. Diantara jeroan dan jaba tengah dipisahkan oleh kori agung.

Kondisi berbeda terdapat di Pura Mekah Banjar Anyar Ubung Kaja. Pura ini tidaklah menggunakan konsep Tri Mandala seperti yang telah dijelaskan di atas, melainkan hanya menggunakan konsep $D w i$ Mandala yang terdiri dari Utama Mandala dan Madya Mandala yang sekaligus berfungsi sebagai jeroan. Wilayah Utama Mandala hanya dibatasi gelung kori dengan wilayah Madya Mandala. Jika mengacu pada penjelasan di atas, maka konsep mandala di Pura Mekah menggunakan Akasa Pertiwi. 
Menurut Pemangku Pura Wayan Mertha di Pura Mekah memang hanya menggunakan konsep Dwi Mandala. Konsep pembangunan ini sudah diwarisinya sejak turun temurun. Dalam arti Mangku Wayan Mertha pun hanya mewarisi keberadaan Pura Mekah seperti keberadaannya yang sekarang. Di sini bisa dijelaskan bahwa secara struktural dengan menggunakan konsep mandala jadi sangat jelas jika pura ini menggunakan konsep $D w i$ Mandala.

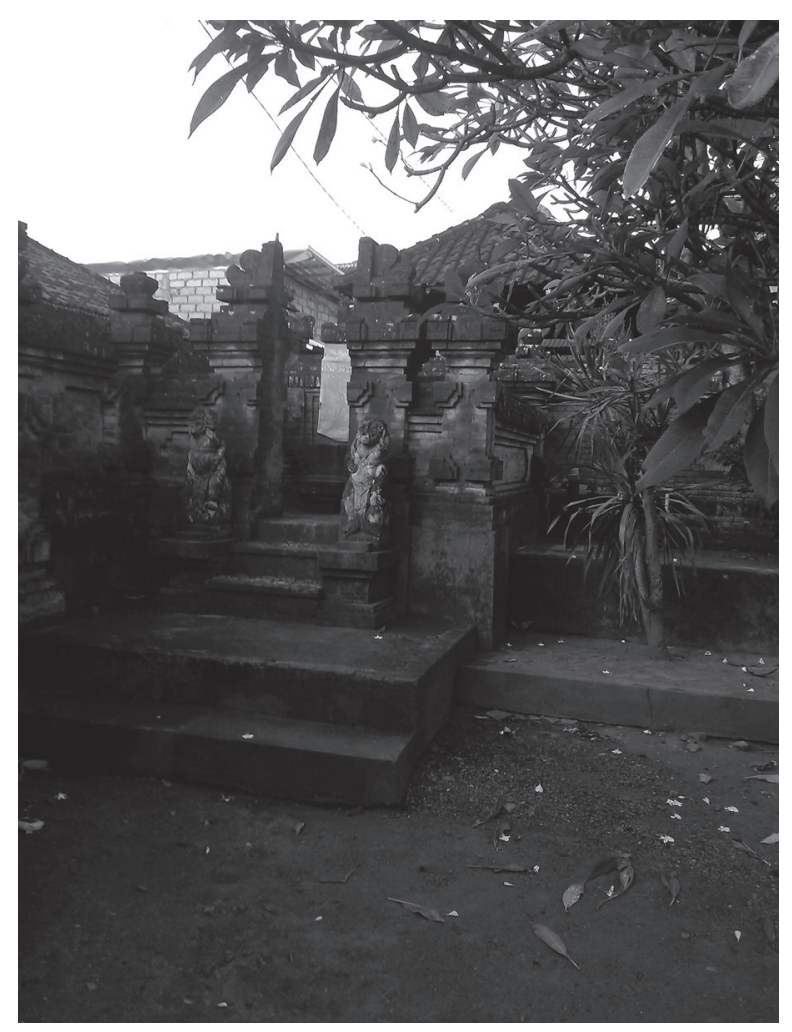

Gambar Penunggun Karang

Dokumentasi Pribadi

Madya Mandala biasanya dimanfaatkan untuk aktivitas ritual yang sifatnya pecaruan, sementara di Utama Mandala biasanya dilaksanakan upacara Dewa Yadnya. Selain itu, di Madya Mandala juga bisa digunakan untuk tempat ngayah keluarga ketika ada patoyan di Pura Mekah. Dari membuat sarana upakara sampai pada masakan yang digunakan untuk upacara.
Seperti yang disampaikan Wayan Mertha:

"Di Madya Mandala ini biasanya digunakan untuk berkumpul ketika membicarakan persiapan menggelar upacara piodalan di Pura Mekah. Bisa dikatakan sebagai tempat paruman. Selain juga untuk tempat ngayah membuat sarana upakara. Memang keberadaan seperti ini, saya juga hanya menerima saja".

Berdasarkan observasi peneliti di lapangan, Pura Mekah ini memang keberadaannya tepat di belakang Banjar Anyar. Jalan masuk ke Pura ini pun sangat sempit. Pintu utama Pura Mekah justru menghadap ke utara. Pura ini juga berdampingan dengan salah satu sekolah dasar di Desda Poh Gading. Sementara pantauan di Madya Mandala Pura memang terdapat Bale Delod yang memang letaknya di sebelah selatan. Sementara di sudut kaje$k a u h$ atau utara-barat terdapat penunggun karang yang dulunya adalah pohon kepuh besar. Menariknya, di sudut timur-selatan justru terdapat Bale Kulkul, letaknya tepat di sebelah timur Bale Delod tadi.

Sementara di Utama Mandala terdapat beberapa bangunan palinggih yang di antaranya adalah Bale Piyasan, Pepelik, palinggih Ratu Hyang, Palinggih Pengoten, Gedong Ratu Gede, Palinggih Pengapit, Palinggih Ratu Ayu, dan tiga balai yang digunakan untuk menstanakan Ida Bhatara ketika diadakan upacara piodalan. Untuk lebih jelaskan khusus untuk denah dan identifikasi tiap-tiap palinggih akan dijelaskan pada sub bab selanjutnya.

\subsubsection{Penyungsung dan Pemangku Pura}

Secara umum istilah penyungsung sesungguhnya memiliki arti yang sama dengan pangempon atau pangemong, karena sama-sama berkaitan dengan umat dan pura, yang berkewajiban menjalankan perintah 
agama dalam melaksanakan sembah sujud bakti kehadapan Tuhan di dalam pura sebagai tempat suci bagi umat Hindu untuk berhubungan dengan Sang Pencipta melalui persembahyangan ataupun persembahan.

Penyungsung berasal dari kata "sungsung" yang berarti junjung, menjunjung atau memuliakan Sang Pencipta ketika bersembahyang di dalam pura. Sedangkan istilah pangempon atau pangemong berasal dari kata "empon" atau "emong" yang mengandung arti mengayomi atau melindungi.

Jadi pengertian penyungsung, pangempon atau pangemong maknanya lebih tertuju kepada umat Hindu yang memuliakan Sang Pencipta dalam menjalankan ajaranagamanya dengan melakukan persembahyangan atau persembahan di dalam pura, dan lebih terkait dengan memberi pengayoman dan perlindungan terhadap keberadaan suatu pura. Dalam konteks pengayoman dan perlindungan, tidak saja secara fisik, melainkan juga dalam finansial dan terselenggaranya keseluruhan kegiatankegiatan upacara yadnya atau pujawali yang di selenggarakan di pura.

Penyungsung atau pengemong di Pura Mekah tidaklah sebanya pura umum, karena status Pura Mekah memang bukan Pura Kahyangan Jagat atau Dang Kahyangan, begitu pula Pura Swagina, melainkan Pura Dadia/Pura keluarga. Oleh sebab itu yang nyungsung Pura Mekah ini tidaklah banyak. Menurut salah satu penyungsung bernama I Made Candra (wawancara 14/4/2016), penyungsung di Pura Mekah kurang lebih sebanyak 20 kepala keluarga. Semuanya adalah orang-orang yang diikat dalam satu hubungan persaudaraan karena pura ini adalah pura dadia. Berikut keterangannya.

"Niki pura keluarga jadi penyungsungnya nenten akeh pak.
Paling banyak kira-kira 20 kepala keluarga. Bahkan ketika ada piodalan biasa yang melaksanakan upacaranya hanya tiga kepala keluarga saja yang nyungsung masing-masing palinggih seperti Ratu Ayu, Ratu Gde dan Ratu Hyang”.

Hal senada juga diungkapkan oleh Pemangku Pura Wayan Mertha, bahwasannya ketika piodalan di hari-hari biasa maka hanya dirinya dan dua kepala keluargalah yang mengadakan upacara piodalan tersebut. Kendati demikian, ia mengaku punya penyungsung sebanyak 20 KK, bahkan bisa mendatangkan $60 \mathrm{KK}$ jika diperlukan. Semua itu adalah sanak saudaranya yang telah kawin mawin. Bisa dikatakan, penyungsung Pura Mekah adalah orang-orang yang memiliki hubungan keluarga dengan Jro Mangku Mertha, selain di Poh Gading ada juga di Peguyangan.

Sementara untuk pemangku sendiri memang dipilih berdasarkan pertimbangan umur, di samping juga faktor keturunan. Seperti diketahui Pamangku Pura adalah orang yang diberikan tugas untuk menghaturkan sesajen atau orang suci disucikan untuk menghantarkan (manggala upacara) suatu sarana upacara yajna. Kalau ada pemedek yang sifatnya pribadi karena suatu kepentingan, pamangku wajib untuk nganteb yang sudah barang tentu dengan etika nuur pamangku. Misalnya dengan canang pengoleman dan canang pemargi.

Pemangku di Pura Mekah bernama I Wayan Mertha. Ia dipilih lantaran usianya yang tergolong tua dan layak dijadikan penglingsir. Wayan Mertha ini tinggal di selatan pura dengan tujuan ketika ada penangkilan ia bisa melayani dengan baik.

\subsubsection{Piodalan di Pura Mekah}

Dalam upacara Yadnya salah satu hal yang tidak bisa dilewatkan begitu saja 
adalah waktu dan tempat upacara itu digelar dan para pemuput upacara sehingga upacara itu jadi sangat ekspresif dan sakral. Pemilihan momentum upacara di Bali sangat penting karena berkaitan dengan dimensi sakral. Khusus untuk di Pura Mekah momentum upacara ritual dilaksanakan setiap Buda Kliwon Pahang. Penetapan hari diadakannya piodalan memang sudah merupakan warisan secara turun-menurun. Jro Mangku Mertha sendiri tidak memiliki alasan kenapa piodalan dilakukan saat Buda Kliwon Pahang, setiap enam bulan sekali.

Ia hanya memahami jika saat itu Ida Bhatara yang berstana di Pura Mekah berkeinginan untuk tedun dan melihat para penyungsungnya. Artinya momen sakral di Pura Mekah memang ditetapkan pada Buda Kliwon Pahang. Untuk rentetan upacaranya sendiri dilakukan sangat sederhana dengan menggunakan banten piodalan biasa dan dipuput oleh Jero Mangku Pura. sementara ketika momentum piodalan bersamaan dengan Purnama, maka dilaksanakan upacara yang Utama dengan menggunakan banten Pulegembal dan dipuput oleh Ida Pedanda.

\subsection{Fungsi Religius}

Menurut Bagus (Mudana, 2003: 87) aspek fungsi merupakan hasil karya yang teratur, terurut dan terpadu yang mengacu pada bagaimana. Fungsi biasanya dianalisis dalam kaitannya dengan manfaat, mengapa suatu tindakan atau interaksi dalam ilmu sosial dilaksanakan. Fungsi mengandaikan bahwa setiap unsur dalam struktur sosial memiliki tujuan masing-masing.

Andrew Lang mengemukakan bahwa asal mula religi adalah kepercayaan terhadap dewa-dewa, dewa tertinggi. Marret menyatakan bahwa bentuk religi yang tertua adalah berdasarkan keyakinan manusia akan adanya kekuatan gaib dalam hal-hal yang luar biasa dan menjadi sebab timbulnya gejala-gejala yang tidak dapat dilakukan manusia.

Koentjaraningrat

(2002:224) mengemukakan bahwa pada mulanya manusia hanya mempergunakan ilmu gaib untuk memecahkan masalah yang ada di luar batas kemampuan dan pengetahuan akalnya. Religi yang ada pada saat itu belum tersirat dalam kebudayaan manusia.

Lambat laun terbukti bahwa banyak dari pada perbuatan magisnya itu ada hasilnya juga, mulailah masyarakat percaya bahwa alam itu didiami oleh makhlukmakhluk yang lebih berkuasa dari padanya. Maka mulailah ia mencari hubungan dengan makhluk-makhluk halus yang mendiami alam itu. Begitulah asal mula timbulnya religi dalam kehidupan manusia. Mengenai upacara religius, Smith (Koentjaraningrat, 1987: 67-68) menjelaskan ada tiga gagasan penting mengenai azas religi dalam agama yaitu sebagai berikut.

(a) Di samping sistem keyakinan dan doktrin, sistem upacara juga merupakan suatu perwujudan dari religi atau agama yang memerlukan studi dan analisa yang khusus.

(b) Upacara religi atau agama, yang biasanya dilaksanakan oleh banyak masyarakat pemeluk religi atau agama yang bersangkutan bersama-sama mempunyai fungsi sosial untuk mengintensifkan solidaritas masyarakat.

(c) Fungsi upacara bersaji, sebagai upacara yang gembira meriah tetapi juga keramat sifatnya.

Berangkat dari penjelasan di atas, religi merupakan sistem keyakinan, juga sistem upacara atau ritual yang terintegrasi dalam satu selebrasi upacara. Religi berawal dari kepercayaan ada kekuatan kosmik dalam dunia - masyarakat primordial menyebutnya yang magis - sebagaimana diungkapkan Frazer. 
Frazer (Pals, 2002:57) menyatakan bahwa asal mula agama adalah magic. Magic adalah tindakan manusia (atau abstensi/penghindaran dari tindakan) untuk mencapai suatu maksud melalui kekuatankekuatan yang ada di dalam alam, termasuk seluruh kompleks anggapan yang ada dibelakangnya.

Lebih lanjut dikatakan oleh Frazer, magis dibangun berdasarkan asumsi bahwa ketika suatu ritual atau perbuatan dilakukan dengan tepat maka akibat yang akan dimunculkan, juga pasti akan dimunculkannya, juga pasti akan terwujud seperti yang diharapkan (Pals, 2002:57). Baik Tylor maupun Frazer adalah tokoh yang menggunakan teori evolusi kebudayaan sebagai dasar pijakan.

Keberadaa Pura Mekah di Banjar Anyar Ubung Kaja juga tidak bisa dilepaskan dari fungsi religius. Setidaknya keberadaan pura ini turut berperan dalam membangun semangat religius masyarakat, khususnya masyarakat penyungsung Pura Mekah. Seperti diketahui, dan sesuai dengan wawancara bersama I Wayan Mertha keberadaan Pura Mekah memang sangat penting dalam membangun kesadaran religius masyarakat khususnya di Ubung Kaja.

Betapa tidak sejak Pura Mekah berdiri hingga kini, masyarakat penyungsung masih rutin melakukan aktivitas religius dari yang sifatnya paling sederhana yakni menghaturkan canang sari dan banten saat purnama-tilem, sampai pada menggelar upacara piodalan. Hal ini dilakukan sematamata untuk memuja Ida Bhatara memohon agar umat manusia diberkati kerayahuan dan kerahajengan. Bisa dikatakan keberadaan Pura Mekah sebagai penopang aktivitas religius masyarakat penyungsung.

Adapun beberapa aktivitas religi yang dilakukan yakni setiap enam bulan sekali tepatnya Buda Kliwon Pahang masyarakat penyungsung Pura Mekah melaksanakan upacara piodalan di Pura Mekah. Seluruh krama penyungsung datang untuk melakukan pemujaan pada Ratu Ayu, Ratu Gede dan Ratu Hyang yang berstana di Pura Mekah. Mereka meyakini jika ketiga Ratu ini melalui kekuatan gaibnya bisa membuat mereka hidup lebih baik dan menemukan kerahayuan.

Biasanya upacara piodalan diawali dengan pecaruan di ruang Madya Mandala. Pecaruan ini diperuntukkan untuk alam bawah atau alam bhuta yang merupakan rencang Ida Bhatara. Selain itu, pada piodalan di Pura Mekah para penyungsung atau pemangku diwajibkan pula untuk mendak tirtha di Pura Desa Peguyangan. Hal ini dilakukan karena merupakan warisan secara turun-temurun. Berikut pernyataan I Wayan Mertha.

"Aktivitas keagamaan memang terlihat setiap hari. Meskipun ini adalah Pura Keluarga, namun ada saja masyarakat di sini yang menghaturkan sesajen memuja beliau. Mereka memohon keselamatan dan kerahayuan. Saya juga kurang tahu kepana mereka datang ke sini. Mungkin saja karena merasakan getaran lain di sini yang merupakan aura dari Ida Bhatara".

Seperti yang disampaikan Mertha, keberadaan Pura Mekah ini setidaknya berdampak pada munculnya kesadarankesadaran religi di kalangan masyarakat sekitar, meskipun pura ini merupakan pura keluarga. Namun tidak menutup kemungkinan masyarakat sekitar yang tidak memiliki hubungan keluarga datang untuk memohon diberikan keselamatan oleh Ida Bhatara Ratu Ayu Manik - ini sebutan masyarakat kepada Ida Bhatara yang berstana di Pura Mekah. 
Selain itu, aktivitas religius di Pura Mekah juga tampak ketika ada piodalan di Pura dalem Poh Gading. Karena pura ini memiliki hubungan khusus, maka ketika ada upacara atau patoyan di Pura Dalem maka Ida Bhatara di Pura Mekah wajib lunga dan ngadeg di wantilan Pura Dalem tersebut. Prosesi ini sudah merupakan rutinitas setiap ada patoyan di Pura Dalem. Prosesi ini juga dimaknai sebagai momen Ida Bhatara tedun ke dunia untuk melaksanakan paruman di Pura tersebut. Upacara ini juga digelar untuk kerahayuan jagat di Desa Poh Gading. Sekali lagi, para penyungsung Pura Mekah akan terlibat dalam prosesi religius ini.

Dari sini bisa disimpulkan jika keberadaan Pura Mekah ini secara langsung memiliki fungsi membangun kembali kesadaran religius masyarakat. Dengan adanya Pura Mekah masyarakat pun seolah diikat dalam satu ikatan spiritual dan religius untuk memuja Ida Bhatara di Pura Mekah. Secara sederhana, ketika ada Pura Mekah, maka masyarakat wajib untuk melaksanakan upacara baik upacara ritual bersaji sampai pada pemujaan terhadap Ida Bhatara yang berstana di sana. Secara sederhana, di mana ada tempat suci, maka di sana pula akan ada para bakta atau pemuja, orang suci, dan upacara-upacara suci. Begitu pula yang terjadi di Pura Mekah ini.

\subsection{Fungsi Sosial}

Selain memiliki fungsi religius seperti yang dijelaskan pada sub bab sebelumnya, keberadaan Pura Mekah juga memiliki fungsi secara sosial. Fungsi upacara-upacara secara sosial sesuai dengan pandangan seorang sosiolog Prancis Emile Durkheim dalam bukunya yang terkenal The Elementary Forms the Religius Life (2011). Durkheim menyatakan bahwa agama adalah sebuah sistem keyakinan dan praktek yang disatukan dengan hal-hal yang sakral, yakni hal-hal yang disisihkan dan terlarang keyakinan dan praktek-praktek yang menyatukan segala hal yang terkait dengan komunitas moral tunggal (Turner, 2006:80).

Selanjutnya Durkheim (Turner, 2006:3) menjelaskan bahwa agama sebenarnya tidak berisi keimanan kepada roh-roh atau dewa-dewa, akan tetapi agama didirikan atas pembedaan kategoris antara dunia yang sakral berhadapan dengan dunia yang profan. Bagi Durkheim keyakinan dan ritus-ritus religious merupakan fakta-fakta sosial yang juga memiliki fungsi integrasi dan menjalin sebuah solidaritas sosial.

Durkheim (Triguna, 1997:98) beragumentasi manusia mengembangkan aktivitas religi bukan karena alam supranatural, tidak pula karena kagum akan kekuatan alam, tidak juga karena ada bayangan abstrak tentang suatu kekuatan yang menyebabkan adanya gerak, tetapi karena danya getaran jiwa yang timbul karena rasa sentimen kemasyarakatan. Wujud dari rasa sentimen kemasyarakatan adalah rasa terikat, rasa bakti, rasa cinta terhadap masyarakat karena manusia merasakan kekuatan gagasan kolektif. Gagasan yang dikemukakan Durkheim ini mewakili apa yang terjadi di Pura Mekah.

Sebagaimana diketahui, status Pura Mekah merupakan pura keluarga atau pura dadia. Status pura keluarga ini membuat Pura Mekah tidak seperti pura umum lainnya. Dalam arti Pura Mekah ini memiliki peran penting dalam memperkuat ikatan keluarga-keluarga penyungsung pura ini. Namun ada persoalan yang menarik ketika peneliti melakukan wawncara dengan Wayan Mertha. Ternyata orang-orang yang selama ini berstatus sebagai penyungsung Pura Mekah hanyalah sedikit kurang lebih 20 kepala keluarga. Bahkan ketika ada piodalan, hanya digarap oleh tiga keluarga saja, termasuk pemangku pura.

Selain itu, para penyungsung Pura 
Mekah juga masih bingun terkait sejarah pura ini dan garis keturunan leluhurnya. Ini mengakibatkan, belum banyak yang tahu jika mereka terikat dalam satu garis lelintihan. Hal ini memang diakui Jro Mangku Mertha. Dirinya pun tidak mengetahui sejarah keberadaan Pura Mekah dan siapa leluhurnya yang mendirikan pura ini. Selama ini, orang mengetahui memiliki hubungan dengan Pura Mekah hanya berdasarkan ikatan keluarga dekat saja. Inilah yang menyebabkan Pura Mekah tidak banyak memiliki pengempon atau penyungsung.

Jro Mangku Mertha mengakui jika pihaknya ingin mengetahui status lelintihannya ini yang berkaitan dengan keberadaan Pura Mekah. Jro Mangku Mertha dan anak-anaknya berencana akan menelusuri babad-babad yang menunjukan keberadaan Pura Mekah. Penelusuran ini penting dilakukan agar Jro Mangku Mertha dan sanak keluarga mengetahui tentang asal usul leluhurnya. Karena sampai saat ini pun dirinya masih belum mengetahui ikwal babad keberadaan Pura Mekah. Berikut pernyataannya:

"Tiang anak sampun napetang pak. Sama sekali tidak tahu sejarah Pura Mekah ini. Yang tiang tahu Pura Mekah adalah warisan leluhur saya dari bapak saya masih hidup. Itu saja yang saya tahu. Maaf sebelumnya pak. Memang banyak orang ke sini mencari data itu, napi kami belum bisa memberikan keterangan lengkap. Melihat situasi itu, kami berencana untuk mencari lelintihan keluarga. Semoga saja ketemu".

Terputusnya informasi tentang status 'darah' keluarga yang nyungsung Pura Mekah ini ternyata memiliki dampak positif juga. Sejak keberadaan Pura Mekah yang masih misteri ini, keluarga Jro Mangku Mertha kompak untuk mencari lelintihan itu. Mereka mulai bersatu untuk menemukan titik terang sejarah asal mula keberadaan mereka dan status soroh mereka. Hal ini dianggap penting dilakukan untuk memberikan kesadaran pada keluarga lain yang memang kawitannya adalah Pura Mekah ini. seperti yang disampaikan Ketut Ardana (wawancara 14/4/2016).

"Menelusuri keberadaan Pura Mekah ini sangat penting pak. Saya sendiri belum memahami keberadannya. Karena ini berkaitan dengan sejaah kami juga. Bisa dikatakan kami masih kepetengan soal itu. Maka dari itu, kami bersatu padu dengan keluarga dekat yang lain untuk menelusuri sejarah leluhur kami. Apalagi saat ini itu penting, jika tidak tahu wit leluhur, maka susah sekarang pak".

Dari keterangan narasumber di atas, maka dapat dijelaskan betapa pentingnya mengungkap keberadaan Pura Mekah ini. Artinya penelusuran Pura Mekah bukan hanya untuk mengetahui sejarahnya, namun juga mengetahui status soroh dan lelintihan mereka yang selama ini belum diketahui. Mereka pun tampak kompak sepakat untuk melakukan penelusuran tersebut. Di sini dapat dilihat keberadaan Pura Mekah ini berfungsi untuk menyatukan kembali hubungan-hubungan darah yang selama ini terputus, sehingga ada ikatan-ikatan keluarga atau sosial di dalamnya. Bisa disimpulkan bahwa Pura Mekah ini memiliki fungsi mempererat kembali hubungan sosial antar keluarga. Pura Mekah mengikat hubungan-hubungan keluarga dan darah yang nyaris terputus itu.

Namun menurut Jro Mangku Mertha, penyungsung Pura Mekah saat ini memang terus bertambah, dari hanya $20 \mathrm{KK}$ sampai 
pada $60 \mathrm{KK}$. Hal ini karena muncul kesadaran keluarga-keluarganya yang lain bahwa Pura Mekah merupakan kawitan mereka selama ini. Kesadaran akan satu kawitan inilah yang mengikat mereka di Pura Mekah, termasuk mulai ikut bertanggung jawa dalam segala jenis kegiatan yang diadakan di Pura Mekah. Dari sini bisa disimpulkan bahwa keberadaan Pura Mekah sangat tampak memiliki fungsi sosial tertentu, mepererat kembali pola-pola hubungan kekerabatan di antara penyungsung pura bahkan masyarakat sekitar.

\subsection{Penutup}

Asal usul keberadaan Pura Mekah di Banjar Anyar Desa Poh Gading Ubung Kaja tidak bisa dilepaskan dari sejarah datangnya Majapahit ke Bali. Secara struktur, Pura Mekah dibangun dengan konsep Dwi Mandala. Pada Madya Mandala terdapat bale delod, penunggung karang dan bale kulkul, sedangkan di Utama Mandala terdapat bangunan seperti, Bale Piyasan, Pepelik/Bale Pangaruman, Palinggih Ratu
Ayu, Pengapit, Gedong Ratu Gede, Palinggih Pengater/Gedong Tiga, Palinggih Ratu Hyang, Bale Pengadegan, dan Bale Gong. Penyungsung Pura Mekah sebanyak 60 Kepala Keluarga dan pujawali dilaksanakan pada Buda Kliwon Pahang.

Fungsi keberadaan Pura Mekah yakni pertama fungsi religius. Keberadaan Pura Mekah berfungsi secara religius. Di Pura Mekah para penyungsung dan masyarakat melaksanakan upacara keagamaan secara rutin setiap enam bulan sekali. Di Pura Mekah juga terdapat tempat pemujaan Ida Bhatara Ratu Ayu, Ida Bhatara Ratu Gede dan Ida Bhatara Ratu Hyang. Selanjutnya fungsi sosial. Pura Mekah juga memiliki fungsi sosial yakni memperkuat ikatan kekerabatan dan kekeluargaan di kalangan pengempon dan penyungsung pura. Saat ini mereka bersatu dalam satu ikatan keluarga untuk menelusuri sejarah keberadaan Pura Mekah termasuk lelintihan mereka. Diperkuatnya ikatan keluarga dan sosial juga terlihat ketika pengempon pura dan masyarakat bergotong royong ketika ada patoyan di Pura Mekah ini. 